\title{
Article
}

\section{A Changing Game: Ethnicity, Gender, and Nation in the US American Soccer Film}

\author{
Haas, Astrid \\ Available at http://clok.uclan.ac.uk/29909/ \\ Haas, Astrid ORCID: 0000-0001-8628-8129 (2014) A Changing Game: \\ Ethnicity, Gender, and Nation in the US American Soccer Film. Comparative \\ American Studies, 12 (4). pp. 301-315. ISSN 1477-5700
}

It is advisable to refer to the publisher's version if you intend to cite from the work. http://dx.doi.org/10.1179/1477570014Z.00000000090

For more information about UCLan's research in this area go to

http://www.uclan.ac.uk/researchgroups/ and search for <name of research Group>.

For information about Research generally at UCLan please go to http://www.uclan.ac.uk/research/

All outputs in CLoK are protected by Intellectual Property Rights law, including Copyright law. Copyright, IPR and Moral Rights for the works on this site are retained by the individual authors and/or other copyright owners. Terms and conditions for use of this material are defined in the policies page. 


\title{
A Changing Game: Ethnicity, Gender, and Nation in the US American Soccer Film
}

\author{
ASTRID HAAS, \\ Bielefeld University, Germany
}

Both sport and film play a key role in contemporary US American popular culture. They are widely regarded as legitimate carriers and formative instances of social identities such as ethnicity, gender, or nationality, and they have capitalized upon one another with increasing success. Soccer and soccer films provide a case in point, as both the sport and its treatment in US American feature films are currently undergoing a change from a rather marginal position to a somewhat secure place within the cultural mainstream. The essay analyses five recent American soccer films with a particular focus on how they frame soccer as an ethnic, gendered, and 'national' game in a US context.

KEYWORDS United States, soccer/football, sport films, gender, ethnicity, migration

\footnotetext{
"The study of sports in American history', Murray Nelson writes, 'is the story of great American themes - racism, sexism, responses to war, demagoguery, sudden economic success, immigration, urban growth, community life, advances in transportation, media hype, and so forth' (2005: 118). In a similar vein, film enjoys a powerful position in US American popular culture, as it has 'evolved into a modern-day family storyteller, assuming the role of instructor through celluloid depictions and images' (Pearson, et al. 2003: 146). Interactions between sport and film in the United States are multiple (Haas, 2011: 151-53), yet one of their major forms is the sport film, one of the most popular cinematographic genres in the country (Baker, 2003: 1; Curry \& Jiobu, 1984: 2). Many American sport films present the depicted sport itself as a vehicle for teaching individual and collective values, such as team spirit, selfreliance, or the belief in the American Dream. While social issues often feature in American sport movies as a historical backdrop of an otherwise non-political narrative, sport movies increasingly 'present competing discourses on class, race, gender, and ... sexuality' and thereby 'contribute to the contested process of defining social identities' (Baker, 2003: 1-2; also 3; Rowe, 1998: 354-57). This is the more relevant, as sport in US American culture often serves
} 
as a field in which social issues are debated, and as screen depictions of a given sport articulate popular understandings of it and its place in United States society. Soccer and soccer films offer a particularly interesting case, as both the sport and its treatment in US American feature films are currently undergoing a change from stepchild to 'new kid on the block' - still minor to the major US spectator sport scene as to the sport film genre but gaining weight in both.

In the following, I will analyse five recent US American soccer films, which deal with the game in an American context. My interpretation is based on a close reading of the films that is set against the backdrop of soccer's history in the United States, on the one hand, and of an (American) cultural studies' approach to sports and sport films, on the other. In so doing, I focus on the changes and continuities in the way the movies depict soccer and its place in United States society. How do they position the sport vis-à-vis hegemonic notions of American national, ethnic, and gender identities? In how far do they perpetuate traditional understandings of these identities? And/or which variations of or alternatives to them do they articulate? To answer these questions, I have selected five of the most widely perceived feature films about soccer in the United States. As based on their respective domestic box office revenues (Sports - Soccer, 2014), these works can be assumed to exert a certain impact on the way the game has been marketed and represented to US cinema audiences since the mid1990s: the children's comedy The Big Green (1995), the coming-of-age movie Goal: The Dream Begins (2005), the historical sport drama The Game of Their Lives (2005), and two films about young female soccer players, Gracie (2007) and Her Best Move (2007).

\section{Soccer in the US}

In contrast to many other countries, US American hegemonic sport culture ${ }^{1}$ has been dominated by baseball, American football, basketball, and ice hockey (Bairner, 2001: 93-106; Markovits \& Hellerman, 2001: 39-98, 128-61). Even though it had been played in the country since the mid-nineteenth century, soccer was regarded as a 'foreign' sport associated especially with lower-class immigrants (Markovits \& Hellerman, 2001: 28, 52-53, 99-108, 121-22, 17172; Wangerin, 2006: 15-44). Moreover, many immigrants' descendants turned to the dominant sports as part of their striving for a US identity (Andrews, 2000: 34-35; Markovits \& Hellerman, 2001: 40, 68-69). Since the 1920s, different attempts have been made to establish a nationwide men's soccer league in the United States. Operating from the late 1960s through the mid-1980s, the North American Soccer League helped trigger the emergence of youth soccer programs at club, school, and college levels (Markovits \& Hellerman, 2001: 109-27, 162-74; Wangerin, 2006: 45-80, 121-60, 165-216). Title IX of the 1972 Federal Education Amendment to the Civil Rights Act of 1964, which forced public educational institutions in the United States to provide women with equal access to and representation within school and college sport, now enabled larger numbers of girls and women to participate in competitive soccer at all playing levels and popularised the game among them (Wangerin, 2006: 292-97, 315-16). Today, soccer is the most popular recreational children's and youth sport as well as the second most widely-practiced team sport in the country (Boesenberg, 2009: 120-21; Giulianotti \& Robertson, 2009: 55). Due to a number of factors, the public perception of soccer in the United States has considerably changed since the 1990s: The game is today accepted as part of the suburban white middle-class lifestyle (Andrews, 2000: 44-50; 
Markovits \& Hellerman, 2001: 171-73), and the recent international achievements of the US women's and men's national soccer teams have gained it a certain recognition as suitable 'American' game. In 1990, the men's team participated in the world cup for the first time since 1950, and it has done so ever since (Wangerin, 2006: 229-38, 247-49, 282-88, 317-23, 334, 337). Selected mainly for economic reasons, the United States hosted the 1994 World Cup to a surprising popular and media interest (Hopkins, 2010: 6-73; Wangerin, 2006: 228-29, 244 63). The women's national team has been even more successful, winning two world cup and three Olympic titles as well as hosting the world cup twice (Hopkins, 2010: 256-84; Wangerin, 2006: 29-300, 313-14, 336-37). Since 1994, the US public and media outlets have been following soccer with growing interest as a quadrennial event akin to the Olympic Games (Markovits \& Hellerman, 2001: 235-63).

In 1996, the national organisers of the 1994 World Cup, backed by major corporate sponsors, launched the division-I men's professional league, Major League Soccer (MLS) 'as the vehicle to reintroduce the sport as a viable cultural and athletic entity to the United States'. ${ }^{2}$ MLS stands out for actively courting the growing Latino population of the country as consumers and fan base by contracting Latino and Latin American players and organising events for Latino audiences, even though the league tends to treat Latinos as a homogeneous group, obliterating their differences in ethnic, class, and national backgrounds (Delgado, 1999: 42, 45-52; Wangerin, 2006: 277-80, 288, 304-05, 329-30, 334-35). While this development somehow re-establishes the 'ethnic' connotation that long contributed to the marginalization of the game, MLS simultaneously targets the largely European-descendant constituency of 'Soccer Americans' (Andrews, 2000: 37; also Markovits \& Hellerman, 2001: 194-95). Today, it is firmly established in the national sport culture and forms a key basis for the achievements of the men's national team. However, MLS still depends on the popularity, visibility, and advertisement value of the world cup, and of the national team's success in particular, to increase public, sponsors', and media interest as well as 'the level of play and the level of pay' (Carlisle, 2010). Management problems, infrastructural deficiencies, and an 'undersized soccer market' (Andrews, 2000: 36) continue to limit the economic and athletic success of the league (Hopkins, 2010: 147-53, 246-55; Wangerin, 2006: 316-17, 323, 331-33, 336). Moreover, not only are black players strikingly underrepresented in MLS and Latinos are at the forefront of players seeking a career abroad (Hopkins, 2010: 239-41; Wangerin, 2006: 334-35). Yet, while many soccer fans in the United States follow other national leagues rather than MLS, especially the growing Latino audience and the engagement of Spanish-language television channels like Univisión in soccer coverage have helped fuel a rising interest in US soccer (Giulianotti \& Robertson, 2009: 56-57; Sharma, et al.).

Despite the popular notion that soccer 'feminises' the US American national sport culture due to the greater media presence of female players in the game (Bairner, 2001: 110), organised soccer in the United States (as elsewhere) is widely geared toward affirming traditional gender norms as well as gendered economic power structures (Boesenberg, 2009: 122-24). Women of colour, though growing in numbers, remain underrepresented as players to date, owing once again to the continuing association of the game with either white middleclass femininity or non-white masculinity, on the one hand, and due to an often-stronger enforcement of traditional gender roles within communities of colour, on the other (Boesenberg, 2009: 124). Moreover, no sustainable division-I professional women's soccer 
league has yet been established. Both the Women's United Soccer Association (2000-2003) and the Women's Professional Soccer League (2009-2012) had to close down after only three seasons for lack of funding (Hopkins, 2010: 201-16; Wangerin, 2006: 310-13, 336). In spring 2013 the National Women's Soccer League (NWSL) began play as a professional women's league and currently encompasses nine teams with plans for further expansion. With only two years to go before the 2015 Women's World Cup in Canada, NWSL receives funding from the national soccer federations of the United States, Mexico, and Canada - a transnational joint venture designated 'to aid the three North American rivals in building and augmenting their national team programs' (Bell, 2013).

\section{Sport culture, film, and social identity construction}

'Popular culture', Michelle Habell-Pallán reminds us, 'is a social and artistic phenomenon through which major cultural and political debates, conflicts, and social expressions about identity, gender, sexuality, community, and nation are staged and performed' (2005: 6). Within US American popular culture, sport plays a central role, which largely stems from 'the twin contradictory notions of sport as magical space and as metaphor for society' (Rowe, 1998: 357). Sport enjoys the status of an autonomous field of private leisure activity, whose enjoyment as participant or spectator unites people across racial/ethnic, gendered, or class barriers. At the same time, it is widely perceived as a legitimate mirror of society (Alkemeyer, 1997: 373-80). This ties in with the widely accepted function of sport for (re)producing conceptualisations of national, racial, and gender identities in the United States. In so doing, sport may act not only as carrier of existing (hegemonic) norms and values but also a site for revising or transforming them (Coakley \& Pike, 2009: 46-48).

According to Murray Nelson, 'the United States prides itself on many things, but few are more prominent and visible than success at a sport' (2005: 118). Both as practice and media spectacle, sport and the popular myths surrounding it serve to generate community cohesion and identification. Sport in the United States has often been taken to symbolise the beliefs in a meritocratic society that offers equal opportunities to everyone, on the one hand, and in industrial capitalism with its principles of fair competition, rationalization, and division of labour, on the other. Consequently, athletic prowess has been promoted as a means of forming character, integrating immigrants, and fostering upward social mobility (Curry \& Jiobu, 1984: 73-80; Bairner, 2001: 97-99, 104-06, 110). The promise of social rise through athletic success particularly appeals to lower-class and minority youth with limited access to higher education and traditional career paths. While only very few athletes realise this 'subdream of the American dream' (Curry \& Jiobu, 1984: 79), those who do so are taken to affirm the myth. This representation and perception of sport reinforces the structural racial and class-related inequalities in the United States, as social differences are related only to individual talent and effort (Bairner, 2001: 111; Curry \& Jiobu, 1984: 103-05). In a similar vein, despite women's achievements in obtaining greater athletic opportunities in the United States, and despite a greater societal acceptance of feminine strength and self-assertion, the qualities many sports require and valorise, such as competitiveness and dominance, continue to be considered as 'masculine'. Therefore, the appeal and the mystification of sport as a 
vehicle for social mobility and character formation are considered legitimate in particular for - and promoted accordingly to - boys and men. Female athletic activity is commonly judged according to its conformity with hegemonic notions of femininity, that is, emphasising grace over strength and co-operation over competition (Baker, 2003: 82-83, 87-88, 143; Coakley \& Pike, 2009: 294-97).

Like sport itself, US sport films produce, affirm, and (occasionally) contest notions of national, gender, and racial identity and hegemonic American values (Pearson, et al. 2003: 14548). Not only does the popularity of sport generate large audiences for sport-themed screen narratives in the country, but the widespread perception of sport as a moral institution and mirror of American life turns the sport movie into a suitable vehicle for educational messages. By drawing upon a set of well-established narrative and thematic formulas and by telling entertaining, emotionally capturing tales of individual struggles for athletic success as well as moral victory, the genre renders social issues accessible to large audiences (Baker, 2003: 2-13, 141-42; Philpott, 2000: 174, 185, 189; Rowe, 1998: 353). The films largely reaffirm the United States' hegemonic self-image a society of equal opportunities that justly rewards personal effort. They especially promote the belief in the American Dream, as they scrutinize competitive excess and violations of fair play yet simultaneously validate competition and individual agency (Pearson, et al. 2003: 148; Philpott, 2000: 177, 186, 189-90; Rowe, 1998: 355-56). In their depiction of US American society, the films largely avoid tackling the structural social inequalities in the United States linked to institutional racism, gender bias, or the exploitation of talent. Many screen depictions of athletes of colour, for instance, emphasise individual success in sport in a way that confirms popular stereotypes of black or Latino collective under-achievement in all other areas of life. Similarly, sport films often equate athletic prowess with hegemonic masculinity in a manner that scrutinizes female competitiveness and self-assertion and thereby reinforces the traditional gender order (Baker, 2003: 3, 25, 30-46, 49-50, 53, 69-70, 73-78; Haas, 2014: 255-63). In the American sport film, Aaron Baker argues, 'the male protagonist defines and proves himself through free and fair competition modeled on American society, which claims that rewards go to the most deserving individuals. Differences in social position are therefore naturalized as evolutionary rather than as a result of a lack of competitive opportunities' (2003: 3; also 49-50).

\section{Ethnic diversity, gender identities, and national imaginaries in the American soccer film}

Hans Blumenberg argues that 'cinema and soccer at first sight appear to have been made for one another: two varieties of popular mass culture, movement-intensive and loaded with emotions, fast-paced and commercial, in their best moments a synthesis of game, art, and entertainment' (qtd. in von Berg, 2002: 200, my trans.). However, due to soccer's traditionally marginal status in US hegemonic sport culture, the rich history of the American sport film includes comparatively few examples of soccer movies. According to Demetrius Pearson et al. (2003: 153-54, 157), not a single soccer-themed sport film was produced in the United States before 1970 and only three such works appeared before 1995. Among them, only the historical drama about soccer in a World War II prisoner of war camp, Escape to Victory (1981), 
is somewhat better known. Similarly scarce is the scholarship on US soccer films, as critical analyses of American sport movies usually ignore soccer-themed works, on the one hand (Baker, 2003; Grob, et al., 2002; Philpott, 2000; Rowe, 1998), and academic writing addressing soccer films almost exclusively focuses on productions from European countries (Moitra, 2007; von Berg, 2002). To this day no study of the US American soccer film exists. The present essay therefore understands itself as an initial intervention that aims at inspiring further investigation in the field, taking its cues from the recent mini-wave of American soccer films. Likely connected to the increasing national interest in, and attendant growing market value of, the sport, a small number of soccer-themed feature films has emerged in the United States since the mid-1990s. In the tradition of the American sport film, but also echoing tendencies in recent European soccer movies such as the British Bend It Like Beckham (2002) or the German The Miracle of Bern (2003) (Moitra 2007: 352-58), some of these works tie athletic to social issues, especially questions of national identity, gender roles, and immigration and ethnic diversity. In the following I will analyse five of these films and the ways they address the named social topics through a soccer-themed narrative.

The Disney children's comedy The Big Green (1995) forms part of the Walt Disney Corporation's strategy to diversify its business activities and better capitalize on the synergies among its brands by engaging in the field of sport entertainment since the early 1990s. Among others, the company produced a series of real-life sport movies that use the arena of sport to promote their vision of the United States as a nation that succeeds through 'optimism, individualism, an ethics of hard work, and the victory of good over evil' (Haas, 2014: 252; also 251). A soccer-themed remake of the first of these films, the ice hockey comedy The Mighty Ducks (1992), The Big Green clearly jumped on the bandwagon of the popular interest in the game the 1994 World Cup had triggered in the United States. It closely follows a narrative formula well established in sport movies and popular in particular in films addressing Disney's target audiences of children and families: Depicting how a ragtag team of 'losers' overcomes various obstacles to become champions on and off the playing field, the films subscribes to a vision of success that honours true effort and exceeding expectations rather than athletic victory alone (Philpott, 2000: 174). The Big Green interweaves this formula with a political narrative of Latino immigration to the United States. Set in a fictive small town in rural Texas, the film shows how the Latino newcomer Juan Morales at first stands out among the local children for his superb soccer play before he wins their friendship. In depicting Juan, The Big Green abstains from the popular stereotypes of Latinos in the United States, even though the juvenile soccer prodigy can be seen as yet another typecast, based on the popular associations of Latin(o) Americans with soccer and of males of colour with athletic prowess, respectively. ${ }^{3}$ The Big Green promotes Juan as a valuable member of American society not only on the grounds of his soccer skills but also because of his ethno-national identity: born in Texas to a Salvadoran political refugee mother, he holds US citizenship and is disconnected from the economically motivated lower-class Mexican immigration many Anglo Americans reject.

Juan's personal story further drives the film's claim that soccer is, indeed, an American sport: Pointing out that in his native town of El Paso 'everybody plays' it (The Big Green, 1995), Juan dissociates soccer from the taint of the 'foreign' game his fellow teammates consider it to be at the beginning of the film. The pivotal scene of The Big Green further invokes another image to assert the Americanness of the sport: During the penalty shootouts of the regional 
championship game, the goalkeeper of the Big Green youth soccer team appears before the inner eye of an opposing striker as a proud Native American chief in full regalia who intimidates his opponent into a bad shot. This recalls the tradition in US sport of appropriating Amerindian imagery, names, and mascots as symbols of national identity tied to notions of 'fierceness and competitive zeal' (Bloom \& Hanson, 2002: 246; also Bairner, 2001: 106-07). In employing the native warrior image, The Big Green suggests that soccer embodies the same 'warlike' spirit as the country's hegemonic sports. The image further adds to the positive vision of a multi-ethnic United States the film unfolds, as the ethnically diverse Big Green team overcomes all kinds of obstacles to finally win the championship against an allwhite team that openly articulates racist attitudes. However, as in real-life appropriations of Native American imagery, the figure of the warrior chief in the film does not pay tribute to the contributions of indigenous peoples to United States culture but 'to extend the political power, secure the social control, and further the economic profit of the dominant culture' (Bloom \& Hanson, 2002: 258).

Another Disney product (through its Disney-owned distributor Buena Vista), Goal! The Dream Begins (2005) echoes the earlier film in valorising the struggles of Latin American immigrants in the United States. In contrast to the team-focused Big Green, Goal! centres on an individual athlete and follows the format of the 'rags-to-riches' sport narrative common in this subtype of the sport film genre. An undocumented immigrant from Mexico living in Los Angeles, the young Santiago Muñez has to overcome a host of personal and athletic obstacles before he makes it to England and the starting line-up of Newcastle United's Premier League team. The first quarter of Goal! depicts Santiago's life in Los Angeles, where he struggles with poverty and a father, who seeks to prevent his son from pursuing the seemingly impossible dream of a professional sports career. In contrast, both his Mexican grandmother and his friends in England encourage Santiago to pursue his goal. It is thus, strikingly, his nonAmerican environment that helps him fulfil the quintessentially 'American Dream'. Yet, as Santiago identifies more strongly with Los Angeles than with Mexico, Goal! symbolically carries the dream itself, albeit not the location of realising it, 'home' to the United States.

Nonetheless, Goal! is clearly geared toward a more international audience than The Big Green, particularly Spanish and Latin American viewers. In addition to the narrative links to Mexico and England, the lead role was cast with well-known Mexican actor Kuno Becker, and some of the playing scenes inserted him into actual footage of Newcastle United matches. Released in Europe and Latin America in fall 2005 and in the United States in spring 2006, the film was geared to draw profits from the global anticipation of the upcoming soccer world cup. Where The Big Green stakes a claim for the Americanness of soccer, Goal! emphasises the global character of the sport and its promise of social rise in a manner that presents the United States as an integral, yet still somewhat marginal part of both the game and the dream. Despite Santiago's identification with Los Angeles, Johannes Binotto aptly observes that, 'as the protagonist first has to travel to England to achieve the rise from worker to superstar, the film makes clear that the American Dream can be realised only in Europe, if anywhere at all' (2005, my trans.). Goal! thus articulates the phenomenon that in the United States inner-city and working-class minorities ... find it hard to break into the largely middle-class suburban world of American soccer' and that especially 'Latino youngsters are choosing overseas [professional] soccer' (Wangerin, 2006: 334-35). From the opening credits that depict little 
Santiago play the game with other boys on a dusty street in Mexico via several scenes featuring him with a Latino youth team in Los Angeles to his life in England, Goal! relates soccer to Latin(o) America, on the one hand, and to Europe (specifically England), on the other. In addition to the protagonist himself, two scenes toward the end of the film finally connect these sport spaces: Both times that Santiago plays in a Premier League match, the film intercuts the actual playing scenes in England with shots of a Los Angeles sports bar, where members of Santiago's Mexican family watch the matches on television together with Anglo fans of his English club.

In his study of the genre, Aaron Baker argues that 'most sports movies that make explicit claims to historical meaning do so ... by portraying the past while looking back in time through the lens of present concerns' (2003: 7). The historical soccer drama The Game of Their Lives (2007) poignantly exemplifies this. Produced by MLS empresario and film producer Philip Anschutz in order to raise interest in his struggling league (Wangerin, 2006: 81), the film tells the story of the historic victory of the US men's national soccer team against England in the first round of the 1950 World Cup. It blends two standard narratives of the sport film genre: the team of 'underdogs' overcoming expectations, on the one hand, and the athletic adversaries forged and gradually growing into a single team, on the other. According to Veronika Grob et al., the sporting team provides an idealised microcosm of United States society: 'The [sporting] team is constituted in American cinema as an ideological field, on which the internal social conflicts are transformed and brought to an imaginary reconciliation' (2002: 78, my trans; also 77, 81). In The Game of Their Lives conflicts within the squad run along intersecting lines of ethnicity, class, region, and playing styles, somewhat stereotypically pitting creative workingclass Italian and Irish Americans from St. Louis against disciplined, bourgeois Anglo, Scottish, and German Americans from the East Coast. What resolves their initial rivalries is their recognising the imperative of growing together as a team in order to represent their country with dignity. Even though The Game of Their Lives ultimately values ethnic diversity, it reiterates certain ethnic and class-related stereotypes as well as stresses the players' identification with the United States as always superseding other social group adhesion. The most striking example includes the film's depicting its only black protagonist. Not only does the Haitian immigrant Joe Gaetjens never encounter racism in the movie; he also repeatedly expresses his love for the United States. At the same time, the film exoticises the striker, who was of upperclass mixed-race ancestry and a practicing Catholic, by casting the role with an actor much darker-skinned than the historical Gaetjens as well as by representing him as a voodoopracticing poor ghetto-dweller (Schaerlaeckens, 2010).

Like The Big Green and in line with its intention to promote professional men's soccer to US audiences, The Game of Their Lives time and again emphasises the Americanness of the game and its practitioners through nostalgically depicting a comparatively unknown incident in the nation's sport history. Roger Philpott observes that 'nostalgia ... invoke[s] memories from which a confirmatory sense of identity can be drawn" (2000: 187). In an early scene in The Game of Their Lives a reporter points out that soccer had been played in St. Louis for 45 years by 1950, and another minor character later invokes the 'American' democratic and egalitarian qualities of the game: In soccer, he tells the players, '[y]ou don't have to be big or strong or tall. It's the most democratic of all sports. The people's game. Your people's game. And America's game of the future' (Game, 2005). The way the film maintains that the 1950 World Cup laid the 
foundation for American soccer's success story further articulates a 'progressive' view of history common in historical (sport) movies, which justifies personal sacrifices and endows the struggles of the past with meaning through their impact for the larger common good in the present (Baker, 2003: 7-8). In line with this position, the appeal of The Game of Their Lives to patriotism and national values resonates in the team coach's admonishing his players that 'it should be a privilege to represent your country, no matter how difficult the circumstances' (Game, 2005). The pivotal match of the US team against England appears to confirm these views. While the English team consists of experienced, highly-skilled professionals and counts a true star player among its ranks, the Americans win the match through 'character and stamina', as their coach puts it (Game, 2005). Like The Big Green, the film strengthens its claim to the Americanness of soccer by linking the game to a vision of a multi-ethnic United States which undermines its contradictory images of either 'white middle-class' or 'ethnic lower-class' sport. Yet, both movies simultaneously contain the 'threat' of immigration by privileging descendants of immigrants over first-generation newcomers: Where Juan in The Big Green is revealed to be a native Texan, The Game of Their Lives has the US-born Walter Bahr lead his team as captain rather than, as historically correct, the first-generation Scottish immigrant Ed McIlvenny.

The two films as well as Goall, however, strikingly differ in their gendered framing of soccer in the United States. Set in the area of children's association sport, The Big Green connects its positive view of an ethnically diverse United States to a society valuing the contributions of girls and women in soccer, as its multi-ethnic bi-gendered team of protagonist players and coaches wins against their misogynist all-male rivals. The Game of Their Lives and Goal!, in contrast, focus on the highly competitive professional adult game, which they represent as an exclusively male activity: This falls in line with the worldwide perception and professionalization history of soccer, on the one hand (Giulianotti \& Robertson, 2009), and with the hegemonic gendered narrative of the American sport film, on the other. The Game of Their Lives and Goal! exclusively show boys and men in connection with the game, whereas women appear only as supportive friends or family members of the soccer-playing male protagonists. Moreover, although the key to success in soccer lies in both positionspecific individual skills and team play, both movies tend to foreground the masculine-coded qualities of physical strength and endurance as relevant factors in the game. They hereby perpetuate what Aaron Baker calls the sport film genre's 'portrayal of non-whites and women as either obstacles that define the hero or faithful supporters of his achievement' (2003: 142).

While Goal! is set in a context in which the 'masculinity' and internationality of (semi-) professional soccer are firmly in place, The Game of Their Lives seeks to further counter the sport's stereotypes of the women's or foreign game. The film does this most prominently in a scene that implies a parallel between the soccer world cup and war. Not only are some of the players on the US national team in The Game of Their Lives veterans of World War II; they also receive their team jerseys in a military ceremony from a general on a US air base in Brazil, who informs them about the beginning of military action in Korea. Through the analogy between competitive soccer and military heroism, the film endows a still widely unknown soccer match with national political relevance and relates the sport to both hegemonic masculinity and American patriotic service. The movie poster and DVD cover clearly underline this claim: Featuring a small group of players standing together with raised fists on a soccer field with an American flag as backdrop, the image vaguely recalls Joe Rosenthal's famous photograph of the 
US Marine Corps, Raising the Flag on Iwo Jima, on the eponymous Japanese World War II battle site in 1945, which has hitherto become a symbol of national heroism and endurance in the face of adversary (Dülffer, 2006). The setting of the movie in 1950 and its linkages to two wars collectively remembered as heroic and justified enables the film to nostalgically remember a bygone past in which hegemonic ideologies of male heroism and female domesticity were firmly in place (Baker, 2003: 66-67). At the same time the film does not address the possibility that the real war could enter into the sport space, as some of the players might be drafted into the armed forces, and hence keeps the soccer narrative 'safe' from war's 'ugly' side of trauma, loss, and invalidity.

This ties in with Aaron Baker's comment on the problematic focus on heroic masculinity in many American sport films. As a consequence, 'when gender discrimination comes up, it is often portrayed not as a systemic flaw in sport competition or American society, but rather as just another ad hoc challenge that the strong and resourceful individual overcomes' (2003: 3, 50). Many screen narratives about female athletes further 'center on how women can participate in sport yet retain a femininity defined primarily by their support for the needs of others, especially men and children' (Baker, 2003: 77). Two American movies about young female soccer prodigies, Gracie (2007) and Her Best Move (2007), perfectly illustrate this observation. Similar to The Big Green, the two films, which were released in the United States shortly before, respectively after the 2007 Women's World Cup, likely sought to capitalise on the national interest in the game in the context of a major tournament with a US team among the major contenders for the title.

Based on the true story of American actress Elizabeth Shue - who plays Gracie's mother and co-produced the film -, Gracie tells the story of New Jersey teenager Grace Bowen, who struggles against the resistance of her family, local community, and school authorities to take the place of her deceased brother Johnny on their high school's varsity soccer team in 1978. Even though she is shown as having enjoyed playing soccer with Johnny, Gracie's decision is mainly presented as a strategy of coping with her loss and of gaining the recognition of her father, who considers girls not tough enough for soccer. Several minor characters echo his resistance to Gracie's ambitions: Her best friend tries to persuade her to give up her plans for fear of being labelled as lesbian through her association with a rough sport, whereas Johnny's former teammates and coach try to prevent Gracie from joining the team and thus to enter a space of male privilege and prestige. Against these forces of resistance, the film stakes a claim for girls' soccer by intertwining female solidarity and US American social values. In a pivotal scene Gracie's mother defends the girl's claim to a place in the try-outs for the team by addressing the school board in an emotional appeal to the American belief in a competitionbased work ethic and the American Dream of success: 'She's fierce', Lindsay Bowen says of her daughter. 'She wants to win. She'll not give up, 'cause she has a dream. For all my boys soccer was and is the most important thing in their lives, and it is the same for Gracie. She loves competing. She loves that win-or-lose life' (Gracie, 2007). In line with this claim, Gracie rewards the Bowen women's effort: Gracie wins a place on the team and is even given Johnny's former jersey number. The ending of the movie moreover links the world of soccer to the sphere of an American teenage girl by having Gracie's soccer uniform of red jersey and dark pants evoke the feminine gear of red tank top and blue miniskirt she wore in earlier scenes. 
The closing credits of the film set Grace Bowen's story into the larger social context by pointing out the crucial role institutional measures like Title IX played for enabling women to obtain athletic recognition in the United States, upon which, among others, the success story of the women's national soccer team is based. Yet, although the movie thus invokes the systemic gender inequalities in the American sport space, Gracie's setting in 1978 and the closing credits' references to the progress that has been achieved since then allow audiences to gloss over ongoing gender discrimination in sport, to which the current struggle to establish a lasting women's professional soccer league in the United States testifies. Moreover, in the way the film reduces collective action to mother-daughter solidarity and connects Gracie's struggle for athletic opportunities to her adherence to the American Dream, it frames a social problem as a personal challenge that demands individual effort rather than structural change.

The MGM-distributed drama Her Best Move takes women's soccer to the very situation of national team success and wider societal acceptance of the game Gracie points out at its end. The film depicts how teenage soccer prodigy Sara tries to juggle a 'regular' girl's life with her own and her father's ambition to become the youngest ever player on the national team development squad. Here, competitive soccer is shown to be a legitimate and joyful activity for girls and young women. Tellingly it is once again connected to the American Dream as a signifier of national identity, when Sara's boyfriend tells her: 'You know what you want and you're going for your dream' (Her Best Move, 2007). Yet, within the context of identification with the nation, Her Best Move follows Gracie in framing girls' soccer almost exclusively as a white Anglo American game. Strikingly, the only non-Anglo player in the film, Sara's teammate and fiercest rival Regina, is a light-skinned Brazilian American, whose ethnicity is underlined through references to Samba and Brazilian soccer. Belonging to an ethnic group widely ignored in US media representations, Regina is removed from the rather negative image attached to Spanish-speaking Latinas/os in the United States. Moreover, as she is strongly characterised by her soccer talent and commitment to her team, she can, akin to Juan in The Big Green, even more easily be framed as a 'good' Latina, the more as she and her immigrant father take great pride in her being nominated for the US national development squad.

Despite its claim to women's right and ability to pursue a highly competitive sport, Her Best Move anchors its sport narrative within the teenage movie genre, which tends to affirm the very gender roles female athleticism at least partially challenges: Like Gracie, the film pays as much attention to Sara's family and high school life as to her athletic activities; it presents competitive soccer less as a legitimate vehicle for female self-fulfilment than as a means for the protagonist to relate to her father; and it shows how Sara's environment, represented here by her mother and best friend, seeks to shift the girl's interests from competitive sport toward more acceptable 'feminine' activities. In so doing, the film joins similar 'films about female athletes [as they] present a disjuncture between scenes in which they demonstrate their ability to appropriate qualities associated with masculinity $\ldots$ and a narrative that pushes them toward compromise with conservative ideas of gender' (Baker, 2003: 50; also 77-78). While Her Best Move features prominent cameo appearances of American soccer star Brandi Chastain, which support a positive image of female athleticism, the movie simultaneously emphasises its connection to mainstream teenage culture and its more traditional notion of femininity by having cast the role of Sara's best friend with actress Lalaine of Lizay McGuire television series fame. Following the 'teenpic' genre's gender ideology, Her Best Move further pits Sara's story 
against Regina's: While the Latina, with her joyful, team-focused soccer play and close-knit family appears as a role model rightfully rewarded with success, the film suggests a causal connection between Sara's dogged ambition, athletic egotism, and estranged family, on the one hand, and her failure in achieving her goals, on the other. Her Best Move thus reinforces the traditional gender order that seeks to contain feminine competitiveness and ambition by demanding that they be integrated into and rendered serviceable to society, represented here by the family and the soccer team.

\section{Conclusion}

Since the 1990s, global soccer has undergone a process of Americanisation, manifest primarily in the growing influence of US American business corporations and customs of mediatisation (Giulianotti \& Robertson, 2009: 51-52). At the same time, soccer in the United States has been subject to a "reverse colonization" or Americolonization, whereby the "global game" penetrates the USA' (Giulianotti \& Robertson, 2009: 55, original emphasis). As I am writing these lines, the performance of the US national team at the current World Cup has incited a veritable 'soccer fever' in the United States, manifest in large public gatherings for watching matches as well as record television and online viewing figures, which may inspire a lasting raised interest in the sport as an American game (Sharma, et al.).

The growing interest in US soccer is somewhat paralleled by the emergence of a series of American movies about the game. Like other forms of cultural production, mainstream film not only articulates popular attitudes to social issues but often also contributes to informing them. As a popular cinematographic genre with a wide audience appeal, sport films offer a telling case, and contemporary American soccer movies provide crucial comments on the changing perceptions of the game as well as help shape them further. While both The Big Green and Goal! highlight the potential of soccer as a vehicle of social rise and acceptance for ethnic minorities, the children's comedy stands out for its positive depiction of a poor immigrant as well as for including female athletic protagonists. Goal!, in contrast, does not challenge the traditional gender order that presents the soccer field as a purely masculine space. Depicting white middle-class girls' struggles to play competitive soccer, Gracie and Her Best Move stake a claim for female athletic prowess. A comparative reading of the films indicates the development towards a greater acceptability of women's physical strength and competitiveness in US American society from Gracie's 1978 to the present of Her Best Move. Nonetheless, the fact that both films carefully seek to reconcile girls' athleticism with notions of hegemonic femininity testifies to the continuing impact of the traditional gender order in American sport and society at large. Contrasting with these endeavours, The Game of Their Lives seeks to counteract the traditional US American view of soccer as a game of either women or immigrants. As it connects soccer to traditional notions of hegemonic masculinity and patriotic heroism, however, the film validates a rather narrow understanding of the game's 'allAmerican' identity. All of the movies analysed in the present essay are moreover marked by their unquestioned heteronormativity, on the one hand, and, on the other, by their aligning with the ongoing tendency in American sport films to accommodate ethnic diversity and 
female athleticism in a manner that validates difference yet upholds a male-, white-, and Anglocentric perspective (Haas, 2014).

\section{References}

Alkemeyer, T. 1997. Sport als Mimesis von Gesellschaft: Zur Aufführung des Sozialen im symbolischen Raum des Sports. Zeitschrift für Semiotik, 19(4): 365-95.

Andrews, D. L. 2000. Contextualizing Suburban Soccer: Consumer Culture, Lifestyle Differentiation and Suburban America. In: G. P. T. Finn \& R. Giulianotti, eds. Football Cultures: Local Contests, Global Visions. London: Cass, pp. 31-53.

Bairner, A. 2001. Sport, Nationalism, and Globalization: European and North American Perspectives. Albany: State University of New York Press.

Baker, A. 2003. Contesting Identities: Sports in American Film. Urbana, IL: University of Illinois Press.

Bell, J. 2013. Another Attempt at Women's Circuit, but With a Twist. New York Times [online] 13 April [Accessed 20 June 2014]. Available at: <http://www.nytimes.com/2013/ 04/14/sports/soccer/national-womens-soccer-league-to-begin-play.html?_r=0>

The Big Green. 1995. Directed by H. G. Sloan [DVD]. Burbank, CA: Buena Vista Pictures.

Binotto, J. 2005. Fussball-Epos in Clip-Ästhetik: 'Goal!' von Danny Cannon. Neue Zürcher Zeitung [online] 21 October [Accessed 20 June 2014]. Available at: <http://www.nzz.ch/aktuell/startseite/articleD8PUX-1.178391>

Bloom, J. \& Hanson, R. 2002. Warriors and Thieves: Appropriations of the Warrior Motif in Representations of Native American Athletes. In: J. Bloom \& M. N. Willard, eds. Sports Matters: Race, Recreation and Culture. New York: New York University Press, pp. 246-63.

Boesenberg, E. 2009. Fußball — ein Frauensport? Transatlantische Sportkulturen im Vergleich. In: M. Penkwitt, ed. Geschlecbter - Bewegungen - Sport. Opladen: Budrich UniPress, pp. 117-27.

Carlisle, J. 2010. Is the tide turning for U.S. soccer? ESPN.com, 12 July [Accessed 20 June 2014]. Available at: $<$ http://espn.go.com/espn/print?id=5363260\&type=story $>$

Coakley, J. \& Pike, E. 2009. Sports in Society: Issues and Controversies. Maidenhead: McGraw-Hill Education.

Curry, T. J. \& Jiobu, R. M. 1984. Sports: A Social Perspective. Englewood Cliffs, NJ: Prentice Hall.

Delgado, F. 1999. Sport and Politics: Major League Soccer, Constitution, and (the) Latino Audience(s). Journal of Sport and Social Issues, 23(1): 41-54.

Dülffer, J. 2006. Über-Helden — Das Bild von Iwo Jima in der Repräsentation des Sieges: Eine Studie zur US-amerikanischen Erinnerungskultur seit 1945. Zeithistorische Forschungen/Studies in Contemporary History [online] 3(2) [Accessed 20 June 2014]. Available at: <http://www.zeithistorischeforschungen.de/site/40208650/default.aspx>

Escape to Victory. 1981. Directed by J. Husto [DVD]. Los angeles: Paramount.

The Game of their Lives. 2005. Directed by D. Anspaugh [DVD]. New York: IFC Films.

Giulianotti, R. \& Robertson, R. 2009. Globalization \& Football. London: SAGE.

Goal! The Dream Begins. 2005. Directed by. D. Cannon [DVD]. Burbank, CA: Buena Vista.

Gracie. 2007. Directed by D. Guggenheim [DVD]. New York: Picturehouse Entertainment.

Grob, V., Janser, D. \& Keller, F. 2002. Auf dem Spielfeld des amerikanischen Traums: Teamsport im Kino Hollywoods. Cinéma: Unabbängige Schweizer Filmzeitschrift, 48: 76-85.

Haas, A. 2011. Latin Skillz: The Fusion of Rap, Film, and Sport in the Mainstreaming of U.S. Latina/o Culture. In: W. Raussert \& M. Habell-Pallán, eds. Cornbread and Cuchifritos: Etbnic Identity Politics, Transnationalization, and Transculturation in American Urban Popular Music. Trier: WVT; Tempe, AZ: Bilingual Press, pp. 151-66. 
Haas, A. 2014. United on the Playing Field? Ethnic and Race Relations in U.S. American Youth Team Sports Films. In: J. Raab, ed. New World Colors: Ethnicity, Belonging, and Difference in the Americas. Trier: WVT; Tempe, AZ: Bilingual Press, pp. 247-65.

Habell-Pallán, M. 2005. Loca Motion: The Travels of Chicana and Latina Popular Culture. New York: New York University Press.

Her Best Move. 2007. Directed by N. Hunter [DVD]. Los Angeles: MGM.

Hopkins, G. 2010. Star-Spangled Soccer: The Selling, Marketing, and Management of Soccer in the USA. Basingstoke: Palgrave Macmillan.

Markovits, A. S. \& Hellerman, S. L. 2001. Offside: Soccer and American Exceptionalism. Princeton: Princeton University Press.

Moitra, S. 2007. Neunzig Minuten Schaulust? Zur Darstellung von Fußball in Spielfilmen des 21. Jahrhunderts. In: J. Mittag \& J.-U. Nieland, eds. Das Spiel mit dem Fußball: Interessen, Projektionen und Vereinnahmungen. Essen: Klartext, pp. 349-58.

Nelson, M. 2005. Sports History as a Vehicle for Social and Cultural Understanding in American History. Social Studies, 96(3): 118-25.

Pearson, D. W., Curtis, R. L., Haney, C. A. \& Zhang, J. J. 2003. Sport Films: Social Dimensions over Time, 1930-1995. Journal of Sport and Social Issues, 27(2): 145-61.

Philpott, R. 2000. Sport in the Cinema. In: L. Allison, ed. Taking Sport Seriously. Oxford: Meyer \& Meyer Sport, pp. 173-92.

Rowe, D. 1998. If You Film It, Will They Come? Sports on Film. Journal of Sport and Social Issues, 22(4): 350-59.

Schaerlaeckens, L. 2010. Chasing Gaetjens. ESPNSoccernet, 26 February [Accessed 20 June 2014]. Available at: <http://ebookbrowsee.net/gaetjens-pdf-d49560414>

Sharma, A., Hagey, K. \& Stevens, L. (2014). Is This Soccer's Moment in America? Wall Street Journal [online] 27 June [Accessed 27 June 2014]. Available at: <http://online.wsj.com/articles/is-thissoccers-moment-in-america-1403819659>

Sports - Soccer. 2014. Box Office Mojo, 22 June [Accessed 23 June 2014]. Available at: $<$ http://www.boxofficemojo.com/genres/chart/?id=soccer.htm>

von Berg, U. 2002. Kino-Kicks: Ein Streifzug durch die Welt des Fußballfilms. In: M. Herzog, ed. Fußball als Kulturphänomen: Kunst — Kult — Kommer:. Stuttgart: Kohlhammer, pp. 197-231.

Wangerin, D. 2006. Soccer in a Football World: The Story of America's Forgotten Game. London: WSC Books.

\section{Notes}

1 Andrei Markovits and Steven Hellerman define 'hegemonic sports culture' as referring to 'the sports culture that dominates a country's emotional attachments rather than its calisthenic activities. This domination need not be exhaustive or total' (2001: 10; also 9-13).

2 Delgado, 1999: 45. On the history of MLS, see Hopkins, 2010: 74-191; Wangerin, 2006: 264-68, 272-81, 288-91, 300-10, 323-36.

3 On the stereotyping of Latinas/os in mainstream US media, see Haas, 2011: 155, 160. 